\title{
Left Heart Haemodynamics at Rest and During Exercise in Patients with Mitral Stenosis
}

\author{
J. KASALICKÝ, J. HURYCH, J. WIDIMSKÝ, R. DEJDAR, R. METYŠ, AND V. STANĚK \\ From the Institute for Cardiovascular Research, Prague- Krč, Budějovická 800, Czechoslovakia
}

Transseptal and retrograde catheterization of the right and left heart (Cournand and Ranges, 1941; Seldinger, 1953; Ross, 1959) provided methods of studying human cardiac haemodynamics on a large scale, which was particularly necessary in view of the widening scope of the surgical treatment of mitral stenosis and other valve defects. In such cases, measurement of left heart pressures and pressure gradients are particularly important.

Increased experience with cardiac catheterization drew attention to the fact that apart from the mechanical obstruction by the stenosed mitral valve, the so-called myocardial factor might also play a role. This assumption of a left ventricular myocardial defect is supported by the following observations made in patients with mitral stenosis: low cardiac output both at rest and during exercise (Harvey et al., 1955), its increase after administration of digitalis (Ferrer et al., 1952), signs of cardiac failure with low cardiac output with normal pulmonary capillary venous pressure (Fleming and Wood, 1959), and increased left ventricular diastolic pressure (Feigenbaum et al., 1966). In such cases, surgical dilatation of the mitral valve cannot bring about the expected improvement; the operation may be even contraindicated because the increased post-operative load on the left ventricle may cause deterioration. Study of this problem has shown that catheterization, at rest, of patients with rheumatic mitral stenosis is inadequate for assessing the cardiac state. It does not take into account the haemodynamics during activity and when performing various types of work. Such conditions may be simulated by subjecting the patient to physical exercise during catheterization. The response to exercise helps to estimate the degree of mitral stenosis on the basis of increased

Received June 1, 1967. pressures proximal to the mitral valve and increased left atrioventricular pressure gradients with increased flow; in addition, physical exercise may also help to uncover further disturbances resulting from pathological conditions of the myocardium.

\section{Subjects AND Methods}

Our series comprised 11 patients and 6 controls. The control group consisted of 6 patients without left heart disease, apical systolic murmurs, and suspected pulmonary embolism. An exception was the man (H.B.) examined for a systolic murmur in the apical region. He had a slightly increased pulmonary capillary venous pressure both at rest and during exercise and a raised pulmonary arterial pressure during exercise, together with a small gradient between the capillary venous and the left ventricular end-diastolic pressures, indicating a haemodynamically insignificant mitral stenosis. Since all the other findings were normal, the patient was included in the control group.

The 11 patients comprising the experimental group had pure or dominant mitral stenosis without other valve lesions of haemodynamic significance. An exception was the patient (B.J.) who had tight mitral stenosis and mitral regurgitation (grade 2/3) demonstrated by anciocardiography. All patients had normal systemic blood pressures.

The investigations were carried out in the morning, in the fasting state, without premedication. First, a single- or double-lumen catheter was inserted through the cubital vein into the pulmonary artery (in three control subjects, into the pulmonary periphery); in the others, another catheter was inserted transseptally into the left atrium and a third catheter was passed retrogradely, using the Seldinger technique, from the femoral artery into the left ventricle. The subjects were allowed to rest for 15-20 minutes; afterwards intracardiac pressures were measured and the cardiac output was measured by the Fick method. The subjects then exercised in the supine position using an ELEMA Schönander bicycle ergometer usually at a load of 250 
$\mathrm{kpm} . / \mathrm{min}$.; if unable to sustain such a load, at 150-200 $\mathrm{kpm} . / \mathrm{min}$. (Tables I and II). Pressures were recorded throughout the exercise. For the calculations, the pressures measured in the 4th minute of exercise were used. The cardiac output was determined between the 4th and 7 th minute of exercise using the Fick method.

Statham electromanometers and the direct-writing Cardirex (Siemens) apparatus were used to obtain the following pressures: pulmonary arterial, left atrial, or pulmonary capillary venous (pulmonary wedge-pressure), and left ventricular; in the course of the examination, the aortic pressure was measured by retrograde catheterization to exclude aortic stenosis. Mean pressures were obtained by electric integration. The phlebostatic plane was situated $5 \mathrm{~cm}$. below Louis' angle. The cardiac output was measured by the Fick method by collecting expired air into a Douglas bag; the $\mathrm{O}_{2}$ and $\mathrm{CO}_{2}$ concentrations were determined by a Zeiss (Jena) interferometer. Blood samples from the pulmonary artery and the left atrium or the left ventricle were withdrawn simultaneously in the middle of the collection period. Oxygen saturation of blood was measured by a Kipp (Delft) haemoreflectometer, and haemoglobin was determined by photometry. After exercise, a majority of the patients was subjected to left heart angiocardiography in order to exclude valvular regurgitation or shunt, and to identify the mitral valve lesion.

Pulmonary vascular resistance (PVR) was calculated and expressed in units from the formula:

$$
\text { PVR }=\frac{\overline{\mathbf{P}}_{\mathrm{PA}}-\overline{\mathbf{P}}_{\mathrm{LA}}\left(\overline{\mathbf{P}}_{\mathrm{cV}}\right) \mathrm{mm} . \mathrm{Hg}}{\text { CO in litres } / \mathrm{min} .}
$$

where $\overline{\mathbf{P}}_{\mathrm{PA}}, \overline{\mathrm{P}}_{\mathrm{LA}}$, and $\overline{\mathrm{P}}_{\mathrm{cv}}$ are the mean pressures in pulmonary artery, left atrium, and wedge positions, respectively, and $\mathrm{CO}$ the cardiac output.

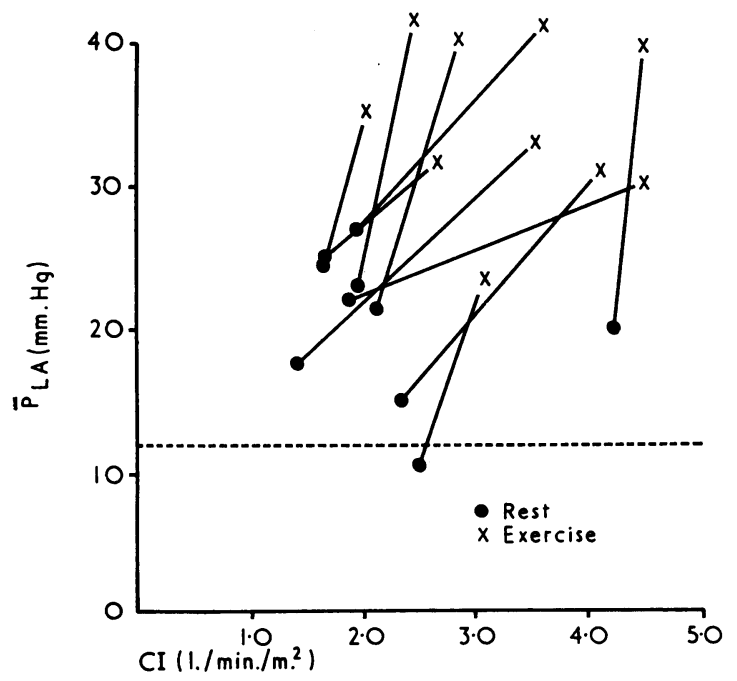

FIG. 1.-The mean left atrial pressure $\left(\overline{\mathbf{P}}_{\mathrm{LA}}\right)-$ cardiac index (CI) ratio at rest and during exercise in patients with mitral stenosis.
Mitral valve area was calculated from the Gorlin formula (Gorlin and Gorlin, 1951).

\section{RESULTS}

Values of the parameters investigated both at rest and during exercise in individual control subjects and patients are presented in Tables I and II.

It is apparent from Table II that patients with mitral stenosis had conspicuous pulmonary hypertension both at rest and during exercise. Pulmonary arterial pressure increased both in control subjects and in patients with mitral stenosis; however, the pulmonary arterial pressure increased during exercise in control subjects on the average by 43.2 per cent, while in patients with mitral stenosis it increased on the average by 79.5 per cent. This increase in pulmonary arterial pressure was a consequence of a high resting left atrial pressure as shown in Table II. Seven patients had resting mean left atrial pressures higher than $20 \mathrm{~mm}$. $\mathrm{Hg}$, indicating that the majority of patients had haemodynamically significant mitral stenosis. During exercise, the mean left atrial pressures increased on the average by 63 per cent of the initial values $(p<0.001)$ while the increases of the left atrial or of the pulmonary capillary venous pressures in control subjects were not significant. From Fig. 1 it is apparent that the increase in left atrial pressure was very steep in relation to the increased blood flow.

The left ventricular end-diastolic pressure in 4 control subjects at rest and in 3 during exercise did

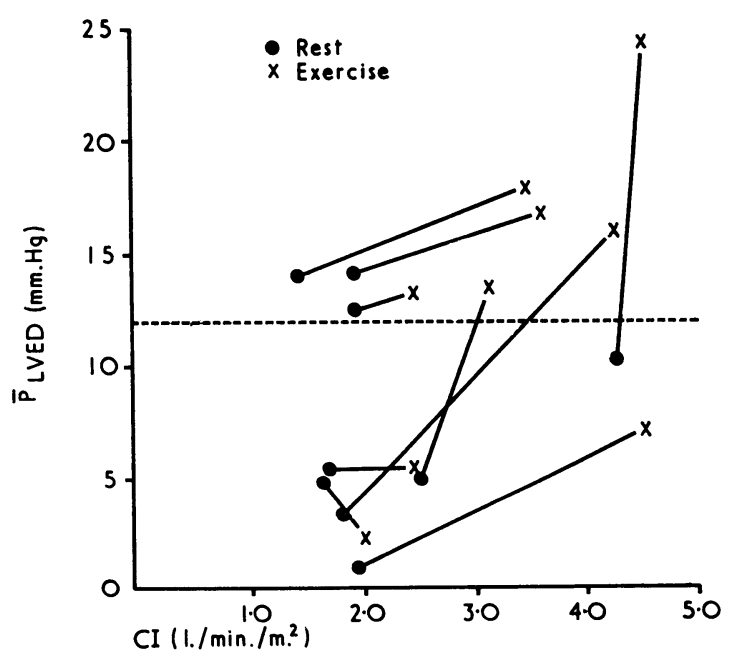

FIG. 2.-The mean left ventricular end-diastolic pressure ( $\overline{\mathbf{P}}_{\text {LVED }}$ - cardiac index $(\mathrm{CI})$ ratio at rest and during exercise in patients with mitral stenosis. 
TABLE

HAEMODYNAMIC DATA IN CONTROL

\begin{tabular}{|c|c|c|c|c|c|c|c|c|c|c|}
\hline \multirow[t]{2}{*}{ Initials, } & \multirow{2}{*}{\multicolumn{2}{|c|}{ age, and sex }} & \multirow[t]{2}{*}{ Diagnosis } & \multirow[t]{2}{*}{$\begin{array}{l}\text { Work } \\
\text { (kpm./ } \\
\text { min.) }\end{array}$} & \multicolumn{2}{|c|}{$\begin{array}{l}\text { Mean pulm. } \\
\text { art. pressure } \\
(\mathrm{mm} . \mathrm{Hg})\end{array}$} & \multicolumn{2}{|c|}{$\begin{array}{l}\text { Mean left atrial } \\
\text { pressure (mean pulm. } \\
\text { capill. venous) } \\
\text { (mm. Hg) }\end{array}$} & \multicolumn{2}{|c|}{$\begin{array}{c}\text { Mean left ventric. } \\
\text { end-diast. } \\
\text { pressure } \\
(\mathrm{mm} . \mathrm{Hg})\end{array}$} \\
\hline & & & & & Rest & Exercise & Rest & Exercise & Rest & Exercise \\
\hline \multirow[t]{2}{*}{$\begin{array}{l}\text { H.B. } \\
\text { S.F. } \\
\text { K.V. } \\
\text { S.V. } \\
\text { K.E. } \\
\text { K.V. }\end{array}$} & $\begin{array}{l}26 \\
41 \\
22 \\
40 \\
35 \\
35\end{array}$ & $\begin{array}{l}M \\
M \\
M \\
M \\
F \\
F\end{array}$ & $\begin{array}{l}\text { Mitral stenosis grade } 1 / 6 \\
\text { Syst. murmur } \\
\text { Syst. murmur } \\
\text { Haemoptysis } \\
\text { Syst. murmur } \\
\text { Syst. murmur }\end{array}$ & $\begin{array}{l}250 \\
250 \\
400 \\
250 \\
250 \\
200\end{array}$ & $\begin{aligned} 18 \cdot 8 \\
10 \cdot 2 \\
7 \cdot 4 \\
18 \cdot 1 \\
14 \cdot 5 \\
10 \cdot 0\end{aligned}$ & $\begin{array}{l}25 \cdot 5 \\
18 \cdot 0 \\
12 \cdot 5 \\
20 \cdot 5 \\
19 \cdot 8 \\
16 \cdot 8\end{array}$ & $\begin{array}{r}14 \cdot 9 \\
2 \cdot 2 \\
3 \cdot 1 \\
9 \cdot 1 \\
0 \cdot 3 \\
1 \cdot 9\end{array}$ & $\begin{array}{r}15 \cdot 6 \\
7 \cdot 2 \\
\overline{9} \cdot 4 \\
5 \cdot 2 \\
1 \cdot 8\end{array}$ & $\begin{array}{c}4 \cdot 9 \\
6 \cdot 5 \\
11 \cdot 4 \\
2 \cdot 2 \\
-\end{array}$ & $\begin{array}{l}9 \cdot 4 \\
9 \cdot 7 \\
10 \cdot 9 \\
=\end{array}$ \\
\hline & \multicolumn{3}{|c|}{$\begin{array}{l}\overline{\mathrm{x}} \\
\mathrm{S} \\
\text { Probability }\end{array}$} & & $\begin{array}{l}+5.68 \\
<0.001\end{array}$ & $\begin{array}{r}18 \cdot 85 \\
68^{4 \cdot 68} \\
001\end{array}$ & \multicolumn{2}{|c|}{$\begin{array}{c}0.80 \\
+2 \cdot 883^{J \cdot 1} \\
\text { NS }\end{array}$} & $\begin{array}{l}+2.56 \\
\text { NS }\end{array}$ & ${ }_{5} \begin{array}{c}10 \cdot 0 \\
0.79\end{array}$ \\
\hline
\end{tabular}

TABLE

HAEMODYNAMIC DATA IN PATIENTS WITH

\begin{tabular}{|c|c|c|c|c|c|c|c|c|c|c|c|c|c|}
\hline \multirow[t]{2}{*}{ Initials, } & \multirow{2}{*}{\multicolumn{2}{|c|}{ age, and sex }} & \multirow[t]{2}{*}{$\begin{array}{c}\text { Grade of } \\
\text { stenosis }\end{array}$} & \multirow[t]{2}{*}{$\begin{array}{l}\text { Mitral } \\
\text { valve } \\
\text { area } \\
\left(\mathrm{cm} \cdot / \mathrm{m} .^{2}\right)\end{array}$} & \multirow[t]{2}{*}{$\begin{array}{l}\text { Work } \\
\text { (kpm./ } \\
\text { min.) }\end{array}$} & \multicolumn{2}{|c|}{$\begin{array}{l}\text { Mean pulm. } \\
\text { art. pressure } \\
(\mathrm{mm} . \mathrm{Hg})\end{array}$} & \multicolumn{2}{|c|}{$\begin{array}{l}\text { Mean left } \\
\text { atrial pressure } \\
(\mathrm{mm} . \mathrm{Hg})\end{array}$} & \multicolumn{2}{|c|}{$\begin{array}{c}\text { Mean left } \\
\text { ventric. } \\
\text { end-diastolic } \\
\text { pressure } \\
(\mathrm{mm} . \mathrm{Hg})\end{array}$} & \multicolumn{2}{|c|}{$\begin{array}{l}\text { Mean left atrial } \\
\text { pressure minus } \\
\text { mean left ventric. } \\
\text { end-diast. pres- } \\
\text { sure (mm. Hg) }\end{array}$} \\
\hline & & & & & & Rest & Exercise & Rest & Exercise & Rest & Exercise & Rest & Exercise \\
\hline $\begin{array}{l}\text { K.E. } \\
\text { P.V. } \\
\text { H.L. } \\
\text { P.L. } \\
\text { B.J. } \\
\text { K.M. } \\
\text { F.A. } \\
\text { F.L. } \\
\text { C.A. } \\
\text { H.M. } \\
\text { S.K. }\end{array}$ & $\begin{array}{l}35 \\
34 \\
38 \\
39 \\
42 \\
49 \\
52 \\
38 \\
52 \\
53 \\
38\end{array}$ & $\begin{array}{l}F \\
M \\
F \\
M \\
M \\
F \\
M \\
M \\
F \\
F \\
M\end{array}$ & $\begin{array}{l}3 / 6 \\
5 / 6 \\
4 / 6 \\
5 / 6 \\
2 / 6^{\star} \\
2 / 6 \\
4 / 6 \\
4 / 6 \\
5 / 6 \\
4 / 6 \\
3 / 6\end{array}$ & $\begin{array}{l}0.5 \\
0.4 \\
0.5 \\
0.9 \\
1.2 \\
1.3 \\
0.5 \\
0.8 \\
1.3 \\
0.3\end{array}$ & $\begin{array}{l}250 \\
150 \\
250 \\
250 \\
250 \\
250 \\
250 \\
250 \\
250 \\
250 \\
250\end{array}$ & $\begin{array}{l}30 \cdot 8 \\
40.5 \\
13 \cdot 1 \\
34.3 \\
21 \cdot 2 \\
26 \cdot 8 \\
20 \cdot 0 \\
50.5 \\
23 \cdot 5 \\
32 \cdot 8 \\
52.5\end{array}$ & \begin{tabular}{|r|}
63.0 \\
62.9 \\
48.5 \\
64.5 \\
33.0 \\
54.5 \\
39.0 \\
62.0 \\
47.0 \\
42.1 \\
116.0
\end{tabular} & $\begin{array}{c}22 \cdot 2 \\
25 \cdot 4 \\
2 \overline{22 \cdot 8} \\
17 \cdot 8 \\
20 \cdot 3 \\
10 \cdot 4 \\
27 \cdot 0 \\
15 \cdot 6 \\
22 \cdot 2 \\
25 \cdot 5\end{array}$ & $\begin{array}{l}29 \cdot 9 \\
30.5 \\
41 \cdot 0 \\
32 \cdot 4 \\
39 \cdot 0 \\
22 \cdot 8 \\
40.5 \\
30 \cdot 3 \\
39 \cdot 8 \\
34.4\end{array}$ & $\begin{array}{r}1 \cdot 0 \\
5 \cdot 4 \\
3 \cdot 4 \\
12 \cdot 4 \\
14 \cdot 0 \\
10 \cdot 3 \\
5 \cdot 0 \\
14 \cdot 0 \\
15 \cdot 0 \\
4 \cdot 8\end{array}$ & $\begin{array}{r}7 \cdot 2 \\
5 \cdot 5 \\
15 \cdot 9 \\
13 \cdot 0 \\
17 \cdot 8 \\
24 \cdot 3 \\
13 \cdot 2 \\
16 \cdot 7 \\
11 \cdot 1 \\
\frac{2 \cdot 3}{}\end{array}$ & $\begin{array}{r}21 \cdot 2 \\
20 \cdot 0 \\
10 \cdot 4 \\
3 \cdot 8 \\
10 \cdot 0 \\
5 \cdot 4 \\
13 \cdot 0 \\
\overline{7 \cdot 2} \\
20 \cdot 2\end{array}$ & $\begin{array}{r}22 \cdot 7 \\
25 \cdot 0 \\
-\overline{28 \cdot 0} \\
14 \cdot 6 \\
14 \cdot 7 \\
9 \cdot 6 \\
23 \cdot 8 \\
19 \cdot 2 \\
-\overline{32 \cdot 1}\end{array}$ \\
\hline \multicolumn{3}{|c|}{$\begin{array}{l}\overline{\mathrm{x}} \\
\mathrm{S} \mathrm{D} \\
\mathrm{d}_{\text {Probability }}\end{array}$} & & & & \multicolumn{2}{|c|}{$\begin{array}{cc}31.45 & 57.50 \\
12.48 & 22.20 \\
+26.05 \\
<0.001\end{array}$} & \multicolumn{2}{|c|}{$\begin{array}{cr}20.87 & 34.06 \\
5.06 & 5.97 \\
+13.19 \\
<0.001\end{array}$} & \multicolumn{2}{|c|}{$\begin{array}{cr}8.53 & 12.7 \\
5.16 & 6.5 \\
+5.06 \\
<0.05\end{array}$} & \multicolumn{2}{|c|}{$\begin{array}{cr}12 \cdot 3 & 21 \cdot 1 \\
6 \cdot 6 & 7 \cdot 2 \\
& +8.31 \\
& <0.001\end{array}$} \\
\hline
\end{tabular}

* This patient had grade $2 / 3$ incompetence as well.

not exceed $12 \mathrm{~mm}$. $\mathrm{Hg}$, which is the upper limit of normal (Braunwald et al., 1961; Samet et al., 1965). End-diastolic pressure in the left ventricle increased during exercise on the average by 49 per cent $(\mathbf{p}<0.05)$. Only the patient (S.K.) with tight mitral stenosis (mitral valve area, $0.32 \mathrm{~cm}^{2} / \mathrm{m}^{2}$ ) had a lower left ventricular end-diastolic pressure during exercise. In 3 patients, end-diastolic pressures increased during exercise by more than $10 \mathrm{~mm}$. $\mathrm{Hg}$. The highest increase was in a woman (patient K.M.) (mitral valve area, $1.25 \mathrm{~cm} .{ }^{2} / \mathrm{m}^{2}{ }^{2}$ ) who also had the highest left ventricular end-diastolic pressure $(24.3 \mathrm{~mm} . \mathrm{Hg})$ of the whole group. The gradient between the left atrial and the left ventricular enddiastolic pressures measured at rest in patients who had left ventricular end-diastolic pressures higher than $12 \mathrm{~mm}$. $\mathrm{Hg}$ averaged $8.6 \mathrm{~mm}$. $\mathrm{Hg}(3.8-13.0)$; on the other hand, in patients who had left ventri- cular end-diastolic pressure higher than $12 \mathrm{~mm} . \mathrm{Hg}$, the corresponding gradient measured during exercise averaged $18 \cdot 1 \mathrm{~mm}$. $\mathrm{Hg}(9 \cdot 6-28 \cdot 0)$. Fig. 2 shows that in 2 patients the increase in left ventricular end-diastolic pressure concurred, with a slight increase of the cardiac index during exercise. The gradient between the left atrial and left ventricular end-diastolic pressures at rest averaged 12.3 $\pm 6 \cdot 6$ $\mathrm{mm} . \mathrm{Hg}$. During exercise the gradient increased by $8.31 \pm 5.2 \mathrm{~mm}$. Hg on the average, reaching a mean value of $21 \cdot 1 \pm 7 \cdot 2 \mathrm{~mm}$. $\mathrm{Hg}$ during exercise for the whole group.

The heart rate increased during exercise both in controls and in patients; in the controls it was slightly higher both at rest and during exercise, but the differences were not significant. The mean oxygen consumption of the patients, both at rest and during exercise, was lower than that of the 
I

GROUP BEFORE AND AFTER EXERCISE

\begin{tabular}{|c|c|c|c|c|c|c|c|c|c|c|c|}
\hline \multicolumn{2}{|c|}{$\underset{\text { rate/min. }}{\text { Heart }}$} & \multicolumn{2}{|c|}{$\underset{\left(\mathrm{ml} . / \mathrm{min} . / \mathrm{m} .^{2}\right)}{\mathrm{O}_{2} \text { consumption }}$} & \multicolumn{2}{|c|}{$\begin{array}{c}\text { A-V } \mathrm{O}_{2} \text { diff. } \\
(\text { vol. } \%)\end{array}$} & \multicolumn{2}{|c|}{$\begin{array}{l}\text { Cardiac index } \\
\left(1 . / \mathrm{min} . / \mathrm{m} .^{2}\right)\end{array}$} & \multicolumn{2}{|c|}{$\begin{array}{l}\text { Stroke index } \\
\left(\mathrm{ml} . / \mathrm{min} . / \mathrm{m} .^{2}\right)\end{array}$} & \multicolumn{2}{|c|}{$\begin{array}{l}\text { Pulm. vasc. } \\
\text { resist. (units) }\end{array}$} \\
\hline Rest & Exercise & Rest & Exercise & Rest & Exercise & Rest & Exercise & Rest & Exercise & Rest & Exercise \\
\hline $\begin{array}{r}105 \\
84 \\
60 \\
60 \\
102 \\
96\end{array}$ & $\begin{array}{r}126 \\
100 \\
84 \\
102 \\
148 \\
126\end{array}$ & $\begin{array}{l}179 \\
213 \\
383 \\
305 \\
190 \\
306\end{array}$ & $\begin{array}{r}662 \\
554 \\
1054 \\
692 \\
713 \\
736\end{array}$ & $\begin{array}{l}4 \cdot 0 \\
4 \cdot 4 \\
4 \cdot 7 \\
4 \cdot 4 \\
4 \cdot 2 \\
5 \cdot 6\end{array}$ & $\begin{array}{l}6 \cdot 7 \\
6 \cdot 8 \\
8 \cdot 75 \\
6 \cdot 6 \\
7 \cdot 2 \\
9 \cdot 45\end{array}$ & $\begin{array}{l}4 \cdot 45 \\
2 \cdot 75 \\
3 \cdot 7 \\
3 \cdot 86 \\
3.08 \\
3 \cdot 49\end{array}$ & $\begin{array}{l}5 \cdot 5 \\
5.1 \\
5 \cdot 47 \\
5 \cdot 85 \\
6 \cdot 73 \\
5.0\end{array}$ & $\begin{array}{l}42 \\
36 \\
62 \\
64 \\
30 \\
37\end{array}$ & $\begin{array}{l}44 \\
51 \\
65 \\
57 \\
45 \\
40\end{array}$ & $\begin{array}{l}0.49 \\
1.65 \\
0.81 \\
1.30 \\
3.27 \\
1.49\end{array}$ & $\begin{array}{l}1.00 \\
1.32 \\
0.43 \\
1.06 \\
1.48 \\
1.92\end{array}$ \\
\hline \multicolumn{2}{|c|}{$\begin{array}{c}84 \cdot 5 \quad 114 \cdot 3 \\
20 \cdot 2923 \cdot 16 \\
+29 \cdot 83 \\
<0.025\end{array}$} & \multicolumn{2}{|c|}{$\begin{array}{cr}262.6 & 686 \cdot 1 \\
81 \cdot 1 & 226.8\end{array}$} & \multicolumn{2}{|c|}{$\begin{array}{l}4.55 \\
0.56 \\
\quad+3.01 \\
\quad<0.001\end{array}$} & \multicolumn{2}{|c|}{$\begin{array}{l}3.55 \\
0.59 \\
+1.05 \\
<0.001\end{array}$} & \multicolumn{2}{|c|}{$\begin{array}{lr}45 \cdot 16 & 50.33 \\
14.37 & 9.35 \\
+5.16 & \end{array}$} & \multicolumn{2}{|c|}{$\begin{array}{l}1.5 \\
0.96 \\
-0.28 \\
\text { NS }\end{array}$} \\
\hline
\end{tabular}

II

MITRAL STENOSIS, BEFORE AND AFTER EXERCISE

\begin{tabular}{|c|c|c|c|c|c|c|c|c|c|c|c|}
\hline \multicolumn{2}{|c|}{ Heart rate/min. } & \multicolumn{2}{|c|}{$\underset{\left(\mathrm{ml} . / \mathrm{min} . / \mathrm{m} .^{2}\right)}{\mathrm{O}_{2} \text { consumption }}$} & \multicolumn{2}{|c|}{$\begin{array}{c}\mathrm{A}-\mathrm{V} \mathrm{O} \mathrm{O}_{2} \text { diff. } \\
(\text { vol. } \%)\end{array}$} & \multicolumn{2}{|c|}{$\begin{array}{c}\text { Cardiac index } \\
\left(1 . / \mathrm{min} . / \mathrm{m}^{2}\right)\end{array}$} & \multicolumn{2}{|c|}{. $\quad$ Stroke index } & \multicolumn{2}{|c|}{$\begin{array}{l}\text { Pulm. vasc. } \\
\text { resist. (units) }\end{array}$} \\
\hline Rest & Exercise & Rest & Exercise & Rest & Exercise & Rest & Exercise & Rest & Exercise & Rest & Exercise \\
\hline $\begin{array}{l}78 \\
96 \\
60 \\
64 \\
69 \\
96 \\
66 \\
72 \\
72 \\
78 \\
60\end{array}$ & $\begin{array}{r}108 \\
102 \\
114 \\
90 \\
102 \\
144 \\
78 \\
102 \\
114 \\
108 \\
96\end{array}$ & $\begin{array}{l}184 \\
133 \\
205 \\
116 \\
104 \\
280 \\
326 \\
333 \\
313 \\
233 \\
129\end{array}$ & $\begin{array}{l}758 \\
239 \\
738 \\
197 \\
340 \\
616 \\
660 \\
702 \\
741 \\
481 \\
268\end{array}$ & $\begin{array}{l}5 \cdot 4 \\
6 \cdot 3 \\
7 \cdot 4 \\
6 \cdot 0 \\
7 \cdot 2 \\
4 \cdot 4 \\
7 \cdot 2 \\
9 \cdot 4 \\
7 \cdot 9 \\
6 \cdot 45 \\
7 \cdot 9\end{array}$ & $\begin{array}{c}9.65 \\
9.6 \\
11.3 \\
8.1 \\
9.8 \\
9.1 \\
11.8 \\
10.7 \\
11.0 \\
9.95 \\
13.0 \\
\end{array}$ & $\begin{array}{l}1.95 \\
1.70 \\
1.83 \\
1.95 \\
1.45 \\
4.25 \\
2.50 \\
1.95 \\
2.40 \\
2.13 \\
1.64 \\
\end{array}$ & $\begin{array}{l}4 \cdot 48 \\
2 \cdot 50 \\
4 \cdot 28 \\
2 \cdot 45 \\
3 \cdot 48 \\
4 \cdot 50 \\
3 \cdot 10 \\
3 \cdot 59 \\
4 \cdot 09 \\
2 \cdot 86 \\
2 \cdot 02\end{array}$ & $\begin{array}{l}25 \\
20 \\
30 \\
30 \\
21 \\
44 \\
38 \\
27 \\
33 \\
27 \\
27\end{array}$ & $\begin{array}{l}42 \\
25 \\
38 \\
27 \\
34 \\
31 \\
40 \\
35 \\
36 \\
26 \\
21\end{array}$ & $\begin{array}{l}2 \cdot 50 \\
4 \cdot 86 \\
2 \cdot 60 \\
1 \cdot 24 \\
1 \cdot 02 \\
2 \cdot 14 \\
6.60 \\
1 \cdot 29 \\
2.94 \\
8.50\end{array}$ & $\begin{array}{l}4 \cdot 20 \\
8.0 \\
4 \cdot 30 \\
0.09 \\
2 \cdot 22 \\
2.90 \\
4.50 \\
2 \cdot 28 \\
0.47 \\
20.0\end{array}$ \\
\hline \multicolumn{2}{|c|}{$\begin{array}{cc}73.7 & 105 \cdot 1 \\
12.59 & 16.62 \\
+28.81 & \\
<0.001\end{array}$} & \multicolumn{2}{|c|}{$\begin{array}{cc}214 \cdot 1 & 521 \cdot 8 \\
88 \cdot 1 & 222 \cdot 6 \\
+ & 300 \cdot 1 \\
& <0.001\end{array}$} & \multicolumn{2}{|c|}{$\begin{array}{cc}6.86 & 10.3 \\
1.36 & 1.65\end{array}$} & \multicolumn{2}{|c|}{$\begin{array}{ll}2 \cdot 16 & 3.39 \\
0.76 & 0.87\end{array}$} & \multicolumn{2}{|c|}{$\begin{array}{rr}29.27 & 32.54 \\
7.05 & 5.16\end{array}$} & \multicolumn{2}{|c|}{$\begin{array}{l}3.37 \\
2 \cdot 5 \\
\quad+1.53 \\
\quad \text { NS }\end{array}$} \\
\hline
\end{tabular}

controls, but again the differences were not significant. The arteriovenous difference was significantly higher $(p<0.001)$ in the patients both at rest and during exercise. The increase in arteriovenous difference during exercise was higher in the patients $(+50.2 \%)$ than in the controls $(+44 \cdot 2 \%)$.

Patients with mitral stenosis had significantly lower cardiac index as well as stroke index both at rest and during exercise compared with the controls (see Table III). Exercise, however, influenced each index differently. The increase in cardiac index above the initial values was practically identical in the control group $(+58 \%)$ and in the patients. with mitral stenosis $(+57 \%)$, whereas only the control group showed a significant $(p<0.05)$ increase in stroke index. In 4 of the patients with mitral stenosis a decrease in stroke index during exercise was observed; the increase in this group averaged only $3.2 \mathrm{ml} . / \mathrm{m}^{2}{ }^{2}$ (in controls +5.17 $\mathrm{ml} . / \mathrm{m}^{2}$ ), and was not statistically significant. A decreased stroke index was also observed in 1 control subject.

Table III shows that the mean pulmonary vascular resistance both at rest and during exercise was higher in the patient group; the differences, however, are not statistically significant. While the mean pulmonary vascular resistance during exercise in the control subjects fell slightly (from $1.5 \mathrm{U}$. to $1.2 \mathrm{U}$.), in the patients it increased (from 3.37 U. to 4.89 U.). The change, however, is statistically not significant because of a wide scatter in the results. During exercise, the PVR increased by more than 10 per cent in 7 patients but decreased in 3. The patient S.K. developed severe pulmonary 


\begin{tabular}{|c|c|c|c|c|c|c|}
\hline & \multicolumn{2}{|c|}{$\begin{array}{l}\text { Mean pulm. art. } \\
\text { pressure (mm. Hg) }\end{array}$} & \multicolumn{2}{|c|}{$\begin{array}{l}\text { Mean left atrial pressure } \\
\text { (mean pulm. capill. venous) } \\
(\mathrm{mm} . \mathrm{Hg})\end{array}$} & \multicolumn{2}{|c|}{$\begin{array}{l}\text { Mean left ventric. end-diast. } \\
\text { pressure }(\mathrm{mm} . \mathrm{Hg})\end{array}$} \\
\hline & Rest & Exercise & Rest & Exercise & Rest & Exercise \\
\hline $\begin{array}{l}\text { Controls } \\
\text { Mitral stenosis }\end{array}$ & $\begin{array}{l}13 \cdot 16 \\
31 \cdot 45\end{array}$ & $\begin{array}{l}18 \cdot 85 \\
57 \cdot 50\end{array}$ & $\begin{array}{r}4 \cdot 86 \\
20 \cdot 87 \\
\end{array}$ & $\begin{array}{r}7 \cdot 75 \\
34 \cdot 06\end{array}$ & $\begin{array}{l}6 \cdot 25 \\
8 \cdot 53\end{array}$ & $\begin{array}{l}10 \cdot 0 \\
12 \cdot 7\end{array}$ \\
\hline Probability & $<0.001$ & $<0.001$ & $<0.001$ & $<0.001$ & NS & NS \\
\hline
\end{tabular}

hypertension during exercise because of an enormous increase of the PVR (from 8.5 U. to $20.0 \mathrm{U}$.).

\section{Discussion}

When it was customary to subject patients with mitral stenosis to right heart catheterization before undertaking planned commissurotomy, several authors pointed out that the reason for the haemodynamic disturbance in such patients was not confined to a mechanical obstacle impeding the blood inflow into the left ventricle (Ferrer et al., 1952; Harvey et al., 1955; Fleming and Wood, 1959). Hence it followed that even a successful dilatation of the mitral valve would not suffice to restore completely normal cardiac function. Post-operative follow-up revealed a certain percentage of patients in whom the operation did not bring about the expected improvement (Harvey et al., 1955; Bergy and Bruce, 1955; Donald et al., 1957; Samet et al., 1959; Basu and Gupta, 1962). In some patients failure to improve correlated with post-operative dilatation of the left ventricle (Soloff and Zatuchni, 1954; Gary, 1956).

A low cardiac output is the main haemodynamic disturbance accompanying mitral stenosis, as shown by our findings which agree with those of other authors (Ferrer et al., 1952; Harvey et al., 1955; Rowe et al., 1960; Bruce et al., 1961; Morbelli, Mascaretti, and Regalia, 1964; Frank, Levinson, and Hellems, 1965; Feigenbaum et al., 1966). The basic cause is a mechanical obstacle impeding good left ventricular diastolic filling.

When the stenosis has been relieved, the rate of flow through the atrioventricular orifice suddenly increases and so a substantially increased load is put on the left ventricle. Physical exercise is the most satisfactory means for bringing about a sudden and substantial increase of blood flow through the left heart and for obtaining information on how the left ventricle will react to the load.

Subjects without cardiopulmonary disturbançes react to physical exercise by an instantaneous rise in cardiac output, proportional to the magnitude of the effort and to the oxygen consumption (Levy,
Tabakin, and Hanson, 1961; Morbelli et al., 1964; Widimský et al., 1965; Levinson, Pacifico, and Frank, 1966; Feigenbaum et al., 1966). In acute and chronic cardiac failure, the cardiac output during exercise either does not increase at all or increases only very slightly (Besterman, 1954; Barger et al., 1961; Harvey et al., 1962).

In patients with mitral stenosis, neither the resting cardiac output nor the increase with exercise reaches the normal values (Morbelli et al., 1964; Frank et al., 1965; Feigenbaum et al., 1966).

Our results agree with these findings. Furthermore, the percentage increase in cardiac index during exercise was similar in those with mitral stenosis and in the controls. The oxygen consumption during exercise rose higher in the control subjects (by $161 \%$ on the average) than in the patients with mitral stenosis (by $143 \%$ on the average). It is interesting that the oxygen consumption was lower both at rest and during exercise in our patients with mitral stenosis, in agreement with data published by Cronin and MacIntosh (1962).

Furthermore, the increase in cardiac output during exercise in patients with mitral stenosis was achieved in a different way. Healthy subjects increase cardiac output by accelerating heart rate and increasing stroke volume (Mitchell, 1963; Levinson et al., 1966), as has been shown in our control group; in our group of patients, however, a distinct increase in stroke volume by more than 10 per cent was seen in only 5 patients, i.e. in less than a half of the group. On the other hand, in two patients the stroke volume fell by more than 10 per cent. The inability of patients with mitral stenosis to increase stroke volume during exercise or under myocardial " stimulation has also been observed by Bruce $e t$ al. (1961). In healthy subjects, on the other hand, a reduced stroke volume occurs only with prolonged severe exercise (Saltin and Sternberg, 1964).

These haemodynamic changes cannot be ascribed to myocardial insufficiency alone. Mitral stenosis creates a mechanical obstacle to left ventricular inflow, particularly when tachycardia is present, as is apparent from the increase in both left ventricular 
III

VALUES IN BOTH GROUPS

\begin{tabular}{|c|c|c|c|c|c|c|c|c|c|c|c|}
\hline \multicolumn{2}{|c|}{ Heart rate/min. } & \multicolumn{2}{|c|}{$\underset{\left(\mathrm{ml} . / \mathrm{min} . / \mathrm{m} .^{2}\right)}{\mathrm{O}_{2} \text { consumption }}$} & \multicolumn{2}{|c|}{$\begin{array}{c}\mathrm{A}-\mathrm{V} \mathrm{O} \mathrm{O}_{2} \text { diff. } \\
(\text { vol. } \%)\end{array}$} & \multicolumn{2}{|c|}{$\begin{array}{l}\text { Cardiac index } \\
\left(1 . / \mathrm{min} . / \mathrm{m}^{2}\right)\end{array}$} & \multicolumn{2}{|c|}{$\begin{array}{l}\text { Stroke index } \\
\left(\mathrm{ml} . / \mathrm{min} . / \mathrm{m}^{2}\right)\end{array}$} & \multicolumn{2}{|c|}{$\begin{array}{l}\text { Pulm. vasc. resist. } \\
\text { (units) }\end{array}$} \\
\hline Rest & Exercise & Rest & Exercise & Rest & Exercise & Rest & Exercise & Rest & Exercise & Rest & Exercise \\
\hline $\begin{array}{l}84 \cdot 5 \\
73 \cdot 7\end{array}$ & $\begin{array}{l}114 \cdot 3 \\
105 \cdot 1\end{array}$ & $\begin{array}{l}262 \cdot 2 \\
214 \cdot 1\end{array}$ & $\begin{array}{l}686 \cdot 1 \\
521 \cdot 8\end{array}$ & $\begin{array}{l}4 \cdot 55 \\
6 \cdot 86\end{array}$ & $\begin{array}{l}7 \cdot 56 \\
10 \cdot 3\end{array}$ & $\begin{array}{l}3 \cdot 55 \\
2 \cdot 16\end{array}$ & $\begin{array}{l}5 \cdot 60 \\
3 \cdot 39\end{array}$ & $\begin{array}{l}45 \cdot 16 \\
29 \cdot 27\end{array}$ & $\begin{array}{l}50 \cdot 33 \\
32 \cdot 54\end{array}$ & $\begin{array}{l}1 \cdot 5 \\
3 \cdot 37\end{array}$ & $\begin{array}{l}1 \cdot 2 \\
4 \cdot 89\end{array}$ \\
\hline NS & NS & NS & NS & $<0.001$ & $<0.001$ & $<0.001$ & $<0.001$ & $<0.05$ & $<0.001$ & NS & NS \\
\hline
\end{tabular}

pressure and pressure gradient (Björk and Malmström, 1959; Silverman et al., 1961). A sudden increase in left atrial pressure and in end-diastolic atrioventricular pressure gradient during exercise, compared with the control subjects, was also observed, in agreement with published data (Litwak et al., 1957; Samet et al., 1959; Frank et al., 1965). Hence it follows that a shortening of the diastolic filling period during exercise leads to an increase in the left atrioventricular pressure gradient, indicating an obstructed forward flow into the left ventricle. Although in mitral stenosis the left ventricle is not overloaded by an increased diastolic volume, either at rest or during exercise, the left ventricular enddiastolic pressure in our patients exceeded the normal upper limit of $12 \mathrm{~mm}$. $\mathrm{Hg}$ in 4 patients at rest and in 6 patients during exercise. The left ventricular end-diastolic pressure during exercise exceeded $15 \mathrm{~mm}$. $\mathrm{Hg}$ in 4 patients; the highest value was $24.3 \mathrm{~mm}$. $\mathrm{Hg}$ (patient K.M.). Feigenbaum et al. (1966) reported similar findings though the physical load on their patients was substantially lower, which is apparent from the smaller increase in oxygen consumption and cardiac output during exercise. On the other hand, neither Gorlin et al. (1965) nor Frank et al. (1965) observed such high values of left ventricular diastolic pressure during exercise.

It is still debatable, however, whether an increase in left ventricular end-diastolic pressure is an accurate sign of left heart failure (Braunwald and Ross, 1963), since no correlation has been found between the end-diastolic pressure and the blood volume in the left ventricle in patients with mitral stenosis. The diastolic left ventricular volume in patients with mitral stenosis did not differ from that in the controls (Folse and Braunwald, 1962; Bristow et al., 1964; Gorlin et al., 1964). Dye dilution techniques, commonly used for estimating end-diastolic blood volume, give excessively high results (Bartle and Sanmarco, 1966; Carleton, Bowyer, and Graettinger, 1966). We may conclude that the resting end-diastolic volume in the left ventricle is not increased in mitral stenosis. In healthy subjects the diastolic volume in the left ventricle diminishes during exercise (Wilson, 1962; Mitchell, 1963), and this tendency seems to occur also in patients with mitral stenosis (Gorlin et al., 1965).

If, therefore, the left ventricular end-diastolic volume in mitral stenosis is not increased at rest or during exercise while the diastolic pressure rises, then the pressure-volume ratio must have been changed as a result of altered properties of the left ventricular wall. The same phenomenon occurs in left ventricular hypertrophy accompanying aortic stenosis (Braunwald and Ross, 1963; Gorlin et al., 1964). In mitral stenosis, however, left ventricular hypertrophy has never been clinically observed (except a single report of Malara, Andreone, and De Giorgi, 1960) and the left ventricular wall is thin. Acute rheumatic disease affects the myocardium by diffuse disintegration of myofibrils which heal by connective tissue replacement closely resembling fibrotic changes in ischaemic heart disease (Clawson, 1940; Murphy, 1959). In the chronic state, similar changes occur in the left ventricle impairing myocardial function.

Our results justify the assumption that some patients with haemodynamically significant mitral stenosis exhibit initial signs of left ventricular failure. For a more accurate evaluation of left ventricular function in such patients, a precise determination of left ventricular blood volume is indicated.

\section{ConClusion}

Eleven patients with pure or dominant mitral stenosis and 6 control subjects were investigated by combined right and left heart catheterization at rest and during exercise. Left atrial and pulmonary artery pressures were significantly increased in patients during exercise, reaching high values. The left atrioventricular end-diastolic pressure gradient was considerably raised. Low cardiac index and stroke index, and decrease of the stroke index during exercise in the patients compared with the control 
subjects, and increased left ventricular enddiastolic pressure in 4 patients at rest and in 6 during exercise represent, in our opinion, early signs of left ventricular failure. Possible causes of this insufficiency are discussed.

\section{REFERENCES}

Barger, A. C., Metcalfe, J. E., Richards, V., and Günther, B. (1961). Circulation during exercise in normal dogs and dogs with cardiac valvular lesions. Amer. F. Physiol., 201, 480.

Bartle, S. H., and Sanmarco, M. E. (1966). Measurement of left ventricular volume by biplane angiocardiography and indicator-washout techniques: a comparison in the canine heart. Circulat. Res., 19, 295.

Basu, A. K., and Gupta, D. Sen (1962). Hæmodynamics in mitral stenosis before, during, and after valvotomy. Brit. Heart f., 24, 445.

Bergy, G. G., and Bruce, R. A. (1955). Discrepancies between subjective and objective responses to mitral commissurotomy. New Engl. F. Med., 253, 887.

Besterman, E. M. M. (1954). The cardiac output in acute rheumatic carditis. Brit. Heart f., 16, 8.

Björk, V. O., and Malmström, G. (1959). The diastolic pressure gradient between the left atrium and the left ventricle in cases of mitral stenosis. Amer. Heart $\mathcal{F}$., $58,486$.

Braunwald, E., Brockenbrough, E. C., Frahm, C. J., and Ross, J., Jr. (1961). Left atrial and left ventricular pressure in subjects without cardiovascular disease. Observations in eighteen patients studied by transseptal left heart catheterization. Circulation, 24, 267.

—, and Ross, J., Jr. (1963). The ventricular end-diastolic pressure. Appraisal of its value in the recognition of ventricular failure in man. Amer. F. Med., 34, 147.

Bristow, J. D., Crislip, R. L., Farrehi, C., Harris, W. E., Lewis, R. P., Sutherland, D. W., and Griswold, H. E. (1964). Left ventricular volume measurements in man by thermodilution. F. clin. Invest., 43, 1015.

Bruce, R. A., Cobb, L. A., Morledge, J. H., and Katsura, S. (1961). Effects of posture, upright exercise, and myocardial stimulation on cardiac output in patients with diseases affecting diastolic filling and effective systolic ejection of the left ventricle. Amer. Heart $\mathcal{F}$., 61, 476.

Carleton, R. A., Bowyer, A. F., and Graettinger, J. S. (1966). Overestimation of left ventricular volume by the indicator dilution technique. Circulat. Res., 18, 248.

Clawson, B. J. (1940). Rheumatic heart disease: An analysis of 796 cases. Amer. Heart f., 20, 454.

Cournand, A., and Ranges, H. A. (1941). Catheterization of the right auricle in man. Proc. Soc. exp. Biol. (N.Y.), 46, 462.

Cronin, R. F. P., and MacIntosh, D. J. (1962). The relationship of oxygen uptake to muscular exercise in patients with mitral stenosis. Dis. Chest, 42, 508.

Donald, K. W., Bishop, J. M., Wade, O. L., and Wormald, P. N. (1957). Cardio-respiratory function two years after mitral valvulotomy. Clin. Sci., 16, 325.

Feigenbaum, H., Campbell, R. W., Wunsch, C. M., and Steinmetz, E. F. (1966). Evaluation of the left ventricle in patients with mitral stenosis. Circuation, 34, 462.

Ferrer, M. I., Harvey, R. M., Cathcart, R. T., Cournand, A., and Richards, D. W. (1952). Hemodynamic studies in rheumatic heart disease. Circulation, 6, 688.

Fleming, H. A., and Wood, P. (1959). The myocardial factor in mitral valve disease. Brit. Heart $\mathcal{F}$., 21, 117.
Folse, R., and Braunwald, E. (1962). Determination of fraction of left ventricular volume ejected per beat and of ventricular end-diastolic and residual volumes. Experimental and clinical observations with a precordial dilution technic. Circulation, 25, 674.

Frank, M. J., Levinson, G. E., and Hellems, H. K. (1965). Left ventricular oxygen consumption, blood flow, and performance in mitral stenosis. Circulation, 31, 824.

Gary, J. E. (1956). Late follow-up study of radiologic changes after mitral valvuloplasty. New Engl. F. Med., 254, 831.

Gorlin, R., Cohen, L. S., Elliott, W. C., Klein, M. D., and Lane, F. J. (1965). Effect of supine exercise on left ventricular volume and oxygen consumption in man. Circulation, 32, 361.

- , and Gorlin, S. G. (1951). Hydraulic formula for calculation of the area of the stenotic mitral valve, other cardiac valves, and central circulatory shunts. Amer. Heart $\mathcal{F}$., 41, 1.

-, Rolett, E. L., Yurchak, P. M., and Elliott, W. C. (1964). Left ventricular volume in man measured by thermodilution. f. clin. Invest., 43, 1203.

Harvey, R. M., Ferrer, M. I., Samet, P., Bader, R. A., Bader, M. E., Cournand, A., and Richards, D. W. (1955). Mechanical and myocardial factors in rheumatic heart disease with mitral stenosis. Circulation, 11, 531.

-, Smith, W. M., Parker, J. O., and Ferrer, I. M. (1962). The response of the abnormal heart to exercise. Circulation, 26, 341.

Levinson, G. E., Pacifico, A. D., and Frank, M. J. (1966). Studies of cardiopulmonary blood volume. Measurement of total cardiopulmonary blood volume in normal human subjects at rest and during exercise. Circulation, 33, 347.

Levy, A. M., Tabakin, B. S., and Hanson, J. S. (1961). Cardiac output in normal men during steady-state exercise utilizing dye-dilution technique. Brit. Heart f., $23,425$.

Litwak, R. S., Samet, P., Bernstein, W. H., Silverman, L. H., Turkewitz, H., and Lesser, M. E. (1957). The effect of exercise upon the mean diastolic left atrial-left ventricular gradient in mitral stenosis. F. thorac. Surg., 34, 449.

Malara, D., Andreone, A., and De Giorgi, E. (1960). Possibilità di ingrandimento del ventricolo sinistro nella stenosi mitralica pura. Studio clinico, elettrocarciografico e radiologico. Minerva cardioangiol., 8, 532.

Mitchell, J. H. (1963). Mechanisms of adaptation of the left ventricle to muscular exercise. Pediatrics, 32, 660.

Morbelli, E., Mascaretti, L., and Regalia, F. (1964). Emodinamica dell'esercizio muscolare nei portatori di stenosi mitralica e nei soggetti affetti da cardiopatia scleroticoipertensiva. Folia cardiol. (Milano), 23, 507.

Murphy, G. E. (1959). On muscle cells, Aschoff bodies, and cardiac failure in rheumatic heart disease. Bull. N.Y. Acad. Med., 35, 619.

Ross, J., Jr. (1959). Transeptal left heart catheterization. A new method of left atrial puncture. Ann. Surg., 149, 395.

Rowe, G. G., Maxwell, G. M., Castillo, C. A., Huston, J. H., and Crumpton, C. W. (1960). Hemodynamics of mitral stenosis with special reference to coronary blood flow and myocardial oxygen consumption. Circulation, 22, 559.

Saltin, B., and Sternberg, J. (1964). Circulatory response to prolonged severe exercise. f. appl. Physiol., 19, 833.

Samet, P., Bernstein, W. H., Medow, A., and Levine, S. (1965). Transeptal left heart dynamics in thirty-two normal subjects. Dis. Chest, 47, 632.

, Litwak, R. S., Bernstein, W. H., Fierer, E. M., and Silverman, L. M. (1959). Clinical and physiologic 
relationships in mitral valve disease. Circulation, 19, 517.

Seldinger, S. I. (1953). Catheter replacement of the needle in percutaneous arteriography. A new technique. Acta radiol. (Stockh.), 39, 368.

Silverman, L. M., Samet, P., Bernstein, W. H., and Litwak, R. S. (1961). Effect of variations in cardiac output and diastolic filling period upon the mitral diastolic gradient. Amer. Heart f., 61, 646.
Soloff, L. A., and Zatuchni, J. (1954). Cardiac enlargement following mitral commissurotomy. Amer. $\mathcal{f}$. med. Sci., 228, 57.

Widimský, J., Kasalický, J., Dejdar, R., and Zajic, F. (1965). Central haemodynamics during muscular exercise in subjects with normal heart and lungs. Cor et vasa (Praha), 7, 143.

Wilson, M. F. (1962). Left ventricular diameter, posture, and exercise. Circulat. Res., 11, 90. 